\title{
Fiscal Policies Applied in Kosovo and Their Impact in the Competitiveness in Kosovar Businesses
}

\author{
Skender Hasani, PhD Cand. \\ University College "Vision for education", Ahmet Kaqiku, 70000 Ferizaj - Kosovo \\ skender_hasani@yahoo.com
}

\section{Doi:10.5901/ajis.2015.v4n1s2p245}

\begin{abstract}
Fiscal policies play an important role in the economic development of a country. Finding more favourable fiscal policies allows not only raising the necessary monetary funds for the functioning of the state but also the distribution of budget revenues in different development projects which will have an important role in economic development and the development of conditions for operation of private businesses as a condition for a sustainable economical growth. While in the after war period in 1999 the goal of fiscal policy has been meeting the immediate needs for normal functioning of life in Kosovo today fiscal policies should be in place for a sustainable economic development which will be a guarantee for state operation thus creating a healthy climate not only for businesses but also for our population. Changes in the world and globalization have had an impact in having a strong competition between different economies, including the economies of most developed countries of the world. As all the economies of other countries so the Kosovo economy as a whole and businesses in particular are not immune to this competition but they daily face these competitiveness issues not only form the competition of regional and European countries, but also from businesses from all continents. The Kosovo economy and the one of all countries in transition faced many difficulties which have affected the development of local businesses and the competitiveness of those businesses compared to businesses in the region and beyond. Through this paper we analyzed fiscal policies that are applied in Kosovo from 1999 to 2014 and we measured the impact of these fiscal policies in the overall development of Kosovo businesses. Particular emphasis in this paper was put on the steps to be taken by the government and substantial reforms to be made in order to establish fiscal and commercial facilities which will affect the growth of local businesses, increase their competitiveness and with it the increase of employment and social welfare of the citizens as a strategic goal for Kosovo and its economy.
\end{abstract}

Keywords: economy, businesses, fiscal policies, competitiveness, reforms

\section{Introduction}

Fiscal policies are a group of all measures undertaken by the State in respect of income, wealth and accumulation made by natural and legal persons for the purpose of fund raising to finance public expenditures. Therefore, through the use of fiscal instruments such as taxes, public expenditures, and public debts etc. state affects all economic costs such as salaries, employment, economic growth etc. The aim of these measures is for the state to have an impact and regulate the cyclical movements in the economy respectively to affect the growth and development of the economy, to increase domestic production and along with the increase of the employment level.

With adequate fiscal policies undertaken by the state, it could affect the employment level and maintain stability in the economy. Kosovo since 1999 until the declaration of independence in 2008 did not have its own autonomous fiscal policies but they have been applied by the United Nations Mission UNMIK through the so-called UNMIK Pillar II Regulation which has been responsible for making and implementation of economic and fiscal policies in Kosovo. By analyzing the results of those fiscal policies it is obvious that they were mainly oriented to maintaining financial stability and very little impact on Kosovo's economic growth, increase of domestic production and along with the increase of competitiveness of SOEs with those of the region and beyond.

After the independence in 2008, although Kosovo was supervised for some time in politics it made in terms of economy, Kosovo has independently created its own fiscal policy but not monetary ones, because Kosovo's official currency is Euro and Kosovo can not impact on the increase or decrease of the cash or other steps, as it is widely known that Kosovo is not a part of the euro zone but due to circumstances it had to have European common currency Euro as the official currency. However the period since 2008 until now even though it was proclaimed that changes were made in fiscal policies compared to those applied by the UNMIK regulation, and that those policies will directly affect the growth of domestic production, growth the competitiveness and profitability of Kosovo businesses, increasing foreign direct 
investment and the level of employment, and that the multiple effects of these measures would be very large and will enable not only maintaining financial stability and sustainability of Kosovo but will have an effect on employment and consumption as an important element of this economic growth, the effects of these changes did not have a significant impact on economic development.

From 2008 until now there are some changes to tax rates which in one way or another are adapted to those in the region but did not create such fiscal policy which would enable the business community in Kosovo to substantially feel them and which would enable businesses in Kosovo competitive to those from abroad, and which would also make foreign investors feel these changes in order to invest their capital in Kosovo and that investment would have an effect on employment, consumption, growth GDP and why not create and increase revenues for the state budget.

\section{Purpose and the Objectives of the Study}

The purpose and objectives of this paper is not only to analyze the rate of economic development of Kosovo, the participation of Kosovo products that are exported to those that are imported, the structure of economic participation but to review and give our contribution to finding better ways to alternation and implementation of such fiscal policies and historical and financial aspects that will affect sustainable economic growth, employment growth, increasing purchasing power of the population which would increase the size of the sensitive effects on economic development.

Economics today on one hand are facing stiff competition from companies abroad, faced with an economy and unfair competition but also significant decrease of the purchasing power of the population. Therefore there is a need for comprehensive analysis of governmental institutions, the business community and civil society in order to find and take radical steps and multidimensional amendments which would help to improve the macroeconomic parameters of Kosovo and the improvement business activity and increasing the competitiveness of Kosovo businesses in comparison with those of other countries.

Kosovo has a low rate of economic growth, which is mainly due to a less favorable environment for business, lack of investment and small financial possibilities and fears of local producers to enter into manufacturing projects, where production carries a higher rist of transfer rate and return on investment for a longer period than those of other sectors of the economy.

The economic growth of 3 percent according to the report of Kosovo Central Bank, as it was assessed during 2014 it is not enough to overcome the many problems with which the Kosovo economy is facing, as many social problems, absorption of new work power entering the labor market every year and which have essential influence on the growth of the purchasing power of citizens because today's economics and household faces shortage of purchasing power which has a chain affects on the overall economy.

Even Kosovo's economic trade balance compared to that of the region and beyond still has a deterioration trend and is extremely unfavorable and due to the policies which have been pursued so far by the government that are oriented more toward coverage of budget needs which still greatly encourages imports than in creating meaningful development policies that would encourage local production and increase the competitiveness of producers and local businesses in their entirety with businesses from other countries.

Therefore even the structure of budget revenues realized so far but also those projected for the future are from the share of revenues from imported goods respectively revenues levied at the border which still remains above 65 percent. These fiscal and developmental policies that have been applied so far in Kosovo have made Kosovo since 2000 until now always to have a large trade deficit and that deficit continues due to these policies, as well as the heavy dependence on imports, the trade deficit in 2012 was 2. 5 billion Euros, in 2013 was 2. 4 billion Euros, and in 2014 was 2. 2 billion Euros. So even though we have a small decrease in trade these last three years this deficit is still high and requires a serious commitment of the governmental relevant decision taking institutions so that this disproportion be mitigated considerably. This can be done only by undertaking of substantial fiscal and developmental reforms that will affect the growth of domestic production and reduce the demand for imported goods.

Fiscal sector was characterized by a slight decrease of revenues and budget expenditures increased during the first half of 2014. Kosovo Budget recorded primary deficit of 22. 0 million Euros to June 2014 (7. 6 million deficit in the same period of 2013 ). General government debt in the reporting period was EUR 554. 4 million or 9. 9 percent of GDP, compared with 9. 1 percent in 2013. Kosovo continues to have the lowest level of general government debt compared with regional countries (58. 1 percent of GDP is the average public debt of countries in the region in 2014). Besides that it 
has the lowest level of public debt, however during 2014 Kosovo has increased it slower compared to the average of the region. ${ }^{1}$

One of the problems highlighted by the business is overseeing the functioning of the market, respectively, unfair competition, which still has large dimensions. All businesses are facing this problem, regardless of the sector in which they operate.

Export has also a very low turnout and a very unfavorable structure, where nearly half of it is accounted for base metals and participation of exports is still very low in volume which in 2014 had a turnout of 324 million Euros, which is much lower than the imports made in Kosovo.

While in 2013 net exports contributed positively to economic growth, as a result of increased exports and decline in imports, net exports in 2014 estimated that contributed negatively to GDP growth by 0.1 percentage points. The deterioration of net exports position during 2014 is estimated to have been a consequence of deepening the goods trade deficit of 2. 6 percent. Exports of goods estimated to have recorded nominal growth of 10. 4 percent (6. 5 percent in 2013), while imports of goods 3. 6 percent (annual decline of 2. 3 percent in 2013). Despite increasing exports, much higher level of imports has made net exports of goods to contribute negatively to growth. Regarding trade in services, the nominal value of their exports estimated to have increased to 14.1 per cent in 2014, while their imports estimated to have increased to 18. 9.

Participation of other items remains low: food and beverages (from 8. 1 in 2005 to 6. 6 percent in 2014), and machinery and mechanical electrical equipment (from 11. 6 percent to 4, 3 percent). There are some minor improvements in the participation of Kosovo in export products such as products of plastics and tires in export which participation has increased from 1.7 percent in 2013 to 6.2 percent, and the share of textile products has grown from 1.1 percent in 2013 to 4.3 percent in 2014 and have increased participation of plant products from 5. 1 in 2013 to 5. 2 percent in 2014.

Such structure of export testifies the low competitive ability of domestic producers, as well as the lack of capital for investment in technology in order to increase the quality, then the acquisition of seductive forms of packaging, as well as more aggressive marketing.

Kosovo faces huge commercial difference and small coverage with import. In the table below the coverage of imports by exports over the years is presented.

Table 1: Kosovo exports and imports with all the countries (000 €)

\begin{tabular}{|c|c|c|c|c|}
\hline Year & Export & Import & Difference & Coverage \\
\hline 2004 & 56,567 & $1,063,347$ & $-1,006,780$ & 5.3 \\
\hline 2005 & 56,283 & $1,157,492$ & $-101,209$ & 4.9 \\
\hline 2006 & 110,774 & $1,305,879$ & $-1,195,105$ & 8.5 \\
\hline 2007 & 165,112 & $1,576,186$ & $-1,411,074$ & 10.5 \\
\hline 2008 & 198,463 & $1,928,236$ & $-1,770,213$ & 10.3 \\
\hline 2009 & 165,328 & $1,935,541$ & $-1,770,213$ & 8.5 \\
\hline 2010 & 295,957 & $2,157,725$ & $-1,861,769$ & 13.7 \\
\hline 2011 & 319,165 & $2,492,348$ & $-2,173,184$ & 12.8 \\
\hline 2012 & 276,100 & $2,507,609$ & $-2,231,509$ & 11.0 \\
\hline 2013 & 293,842 & $2,449,064$ & $-2,155,222$ & 12.0 \\
\hline 2014 & 324,554 & $2,538,232$ & $-2,213,678$ & 12.78 \\
\hline \hline
\end{tabular}

${ }^{1}$ Kosovo Central Bank, Report on macroeconomic developments, number 2, February 2015 


\begin{tabular}{|c|c|c|}
\hline $\begin{array}{l}\text { Kosovo } \\
\text { Goods exempt from customs } \\
\text { - Exports } \\
\text { - Diplomatic or consular missions and their staff } \\
\text { - Import of goods which are for the official use of } \\
\text { UN or any of its organ } \\
\text { - UNMIK, specialized agencies, KNKK, KFOR, } \\
\text { EULEX } \\
\text { - Import of goods financed by grants awarded by } \\
\text { governments, governmental agencies, } \\
\text { governmental and non-governmental } \\
\text { organizations to assist programs and } \\
\text { humanitarian projects such as those for Kosovo's } \\
\text { reconstruction. } \\
\text { - Imports of specific goods for which Kosovo } \\
\text { Government decides that should be used for } \\
\text { humanitarian purposes. } \\
\text { - Zero custom tax for a wide spectrum of raw } \\
\text { material and equipments } \\
\text { - Removal of double taxation with Albania }\end{array}$ & $\begin{array}{l}\text { Macedonia } \\
\text { - Incentives in areas of industrial } \\
\text { technological development } \\
\text { - Corporate profit tax -0 (outside } \\
\text { the area } 10 \% \text { ); } \\
\text { - Personal Income Tax } 0 \\
\text { (outside the area - } 10 \% \text { ); } \\
\text { - VAT - } 0 \\
\text { (outside area } 18 \% \text { ) } \\
\text { - Excise } 0 \\
\text { ( outside the area 5-62 \%); } \\
\text { - Processing materials and } \\
\text { equipment are exempt from } \\
\text { customs duty }\end{array}$ & $\begin{array}{l}\text { Serbia } \\
\text { - For big projects: grants up to } 20 \% \\
\text { of investments; } \\
\text { - For projects of wide standards: } \\
4,000-20,000 \text { euro for a new working } \\
\text { place; } \\
\text { - For big investments: } 10 \text { years break } \\
\text { from Corporate income tax; } \\
\text { - For investments: tax credit on } \\
\text { corporate income to } 40 \% \text { of } \\
\text { investments in real estate; } \\
\text { - Removal of double taxation; } \\
\text { - Exemptions from tax charges on } \\
\text { wages and social security; } \\
\text { - Annual income tax deduction up to } \\
50 \% \text { of taxable income }\end{array}$ \\
\hline
\end{tabular}

Source: Kosovo Agency of Statistics, Ekonomik Statistics, Januar 2015; page 9

Situated in Eastern Europe, Kosovo's economy has become part of the economic integration of the region, providing market expansion opportunities. Aim in itself already is to increase its competitiveness by increasing export capacity to reduce the trade deficit that Kosovo currently has.

As an important location for business development, Kosovo offers a range of comparative priorities as young population and somewhat qualified, natural resources, favorable climatic conditions, new infrastructure, fiscal policy with the lowest taxes in the region tax, geographic position with access to the regional market CEFTA and in the on of the European Union.

The government does not open new jobs but creates the possibility for their opening in this case the unemployment rate will decrease and the reduction of powerty and other chain effects on local businesses as well. Channeling budget in several major infrastructures projects but not in projects that would affect the growth of productive capacity of Kosovo businesses and the reduction of the dependence of imported products are some of the elements which should have been and should be urgently taken by relevant state institutions. Kosovo has a high potential for agricultural production and for building processing capacities of these products which would enable not only the reduction of the import of these products but also the employment growth of a large number of people including those in the agricultural and industrial capacity.

But if you compare measures and facilities that the Kosovo government has done we could say that Kosovo has significantly stalled in proposing initiatives and creating various facilities for manufacturing businesses especially for those businesses that employ a lot of people, create added value over half in Kosovo and their products are export-oriented. Besides the release of certain imported goods from customs tax - mainly in machinery and less on raw material, no other measure that facilitates doing business has been taken. On the other hand, countries in the region, such as Serbia and Macedonia provide investment incentives, tax holidays, use the parcels whole infrastructure.

So far, some of the steps that have been undertaken by government institutions are:

1. Subsidy of several activities with an emphasis on agriculture;

2. Facilitating and accelerating the procedures for business registration;

3. Facilitation of some customs procedures;

4. The guarantee of deposits to 2000 Euros;

5. Reducing the tax on business income.

But the undertaking of these steps did not have the expected impact because Kosovo manufacturers and Kosovo businesses are still faring numerous difficulties which have played a decisive role that although there have been some actions and reforms of government institutions they still have not played the effect which is intended by the government.

If we analyze only the effects of the reforms outlined above we can conclude that those steps shave not been sufficient and have been deficient since we are in a situation where: 
The level of subsidy for agricultural activities has not created conditions for local products to be competitive against those imported neither in terms of price nor quality.

Facilitation of business registration procedures was not followed by other facilities in obtaining other necessary permits to develop the activity for which they have invested their capital.

Facilitation of customs procedures has failed to stop the informal economy which developed mainly from import goods since the import export ratio today is 88/12.

Although the guaranteed deposits are up to 2000 we still have the highest rates of interest in the region and beyond and it directly affects the difficulty of financing various projects by businesses in Kosovo.

Reduction of taxes on corporate income from $20 \%$ in 2009 to $10 \%$ is not accompanied by the combat of informal economy the rate of which, according to statistics of different institutions of the economy, ranges from $28-33 \%$ from the gross general product which for 2013 was EUR 5,800,000. 00 in Kosovo.

\section{Research Question - Methodology of Treatment}

The purpose of this paper is to revie what actual steps have been undertaken by the state institutions so that the economics in general and businesses in particular to help businesses overcome difficulties of their occasional cases as a result of those streams.

Based on this relevant Kosovar institutions have tended to undertake a number of actual steps that would create a favorable climate for business, to arrange for Kosovar businesses to be equal to the conditions of doing business offered to businesses in other countries, however based on the responses received from a number of Kosovo businesses we can say that the businesses are not satisfied with the steps which were taken by institutions due to the obstacles that arise in their business either because of shortcomings in legislation or due to failure to legislation by the authorities.

With the aim of analyzing these steps which were taken by relevant institutions and analyzing the situation of doing business in Kosovo we have prepared a questionnaire and sent it to a significant number of Kosovar businesses from whom we asked to answer a number of questions which we deemed relevant and which can give a clearer picture of their situation and their perception of the steps taken by the government. Of the total number of over 10,000 businesses registered in Prishtina region and which develop business (information obtained from the Tax Administration of Kosovo) we analyzed the information returned by 100 businesses of different activities 50 in trade and services and 50 in production )that have been answered and their perception on doing business, their difficulties and other elements that accompany their daily activities.

\section{Analyses - Interpretation of Data}

In order to accomplish this paper we have interviewed 100 businesses in various activities 50 from tham in trade and services and 50 in filed of production where we have submitted sever questions to business leaders in which they have responded mainly with Yes or No.

Table with questions and answers by various respondents in trade and services

\begin{tabular}{|c|l|c|c|}
\hline No. & Research question & Yes & No \\
\hline 1 & Do you think that doing business in Kosovo is difficult? & 49 & 1 \\
\hline 2 & Did you increase turnover from 2008 onwards? & 27 & 23 \\
\hline 3 & Did you increase employment from 2008 onwards? & 15 & 35 \\
\hline 4 & Did you increase profit from 2008 onwards? & 16 & 34 \\
\hline 5 & Do you think that the Government has undertaken sufficient steps to overcome the business difficulties in Kosovo? & 4 & 46 \\
\hline 6 & Did you benefit from any subsidies or grants from the Government of Kosovo? & 13 & 37 \\
\hline 7 & $\begin{array}{l}\text { Do you think that the conditions of doing business in Kosovo are more favorable compared to other countries in the } \\
\text { region? }\end{array}$ & 9 & 41 \\
\hline 8 & Do you think that the legal infrastructure is sufficient to protect your investments in Kosovo? & 17 & 33 \\
\hline 9 & Would you transfer your business activity in the region or abroad if you had the opportunity? & 37 & 13 \\
\hline 10 & $\begin{array}{l}\text { Do you think that the Government should do fiscal political reforms in order to create a more favorable climate for } \\
\text { businesses? }\end{array}$ & 46 & 4 \\
\hline
\end{tabular}


Table with questions and answers by various respondents in production

\begin{tabular}{|c|l|c|c|}
\hline No. & Research question & Yes & No \\
\hline 1 & $\begin{array}{l}\text { Do you think that the Government should do fiscal political reforms in order to create a more favorable climate for } \\
\text { businesses? }\end{array}$ & 50 & 0 \\
\hline 2 & $\begin{array}{l}\text { Do you think that the conditions of doing business in Kosovo are more favorable compared to other countries in the } \\
\text { region? }\end{array}$ & 4 & 46 \\
\hline 3 & Do you think that the Government has undertaken sufficient steps to overcome the business difficulties in Kosovo? & 3 & 47 \\
\hline 4 & Did you benefit from any subsidies or grants from the Government of Kosovo? & 11 & 39 \\
\hline 5 & Do you think the producers should be exempt from customs duties on raw materials? & 50 & 0 \\
\hline 6 & Do you think the producers should be exempt from VAT on raw materials? & 50 & 0 \\
\hline 7 & $\begin{array}{l}\text { Do you think the government should subsidize local producers especially ex } \\
\text { porters? }\end{array}$ & 50 & 0 \\
\hline 8 & Are your products competitive in terms of quality compared to other imported products? & 32 & 18 \\
\hline 9 & Are your products competitive in terms of price compared to other imported products? & 29 & 21 \\
\hline 10 & Do you have difficulty in placing your products from unfair competition in goods similar to what you produce? & 24 & 26 \\
\hline
\end{tabular}

From the information obtained from the interviews which were conducted with a significant number of businesses we can emphasize that most of them are not satisfied with the conditions that exist for doing business in Kosovo and believe that doing business is very difficult and this does not come as a result of the taxation system in Kosovo because fiscal charges in Kosovo are quite small but this difficulty is caused by other associated elements of business activities such as:

Considerably high scale informal economy which affects an unfair competition compared to businesses that conduct their activities in accordance with applicable rules and legislation in Kosovo.

Lack of an efficient and reliable judiciary in resolving various disputes between businesses;

Unfavorable loan system for businesses;

Provision of subsidies and grants for a sustainable economy based on disciplines that are most needed and not on the basis of parameters wich are not properly analyzed.

\section{Conclusion - Recommendation}

From data obtained as from the interviews conducted with a large number of businesses or even obtained from the relevant local and international institutions operating in Kosovo, it can be concluded that the steps which were taken by the relevant state institutions were not sufficient to establish a stable climate of doing business in Kosovo and therefore this situation has had an impact in businesses having significant difficulties and it has led to having businesses, a part of them, cease their activities, another part of them transferring their activities in other countries of the region and a part of them working with various difficulties, which may affect them in the future to have the fate of some businesses that have closed or transferred their capital abroad.

Therefore based on the above we can conclude that it is quite necessary to undertake some substantial reforms with the aim of creating equal conditions, for businesses that develop activities in Kosovo, to those from the region and beyond, those steps are:

1. Exemption from customs duties and VAT for all imported raw materials

2. Subsidizing certain percentage of capital for new investments in infrastructure and machinery in manufacturing depending on the number of workers that the business would employ

3. Tax break for withholding tax, social contributions and profit tax depending on the number of employees the company employs

4. The escalation of VAT for products and exemption from VAT for deficient products

5. Automatic reimbursement of VAT with the aim of introducing instruments in circulation

6. Creating infrastructure conditions not only in the road but power supply, water and other elements which are necessary for the creation of a stability for businesses operating in Kosovo;

7. Use of intellectual capacity and experience from various areas of business;

8. Creating the conditions for foreign direct investment.

\section{References}

Statistical Office of Kosovo. (2014). Economic Statistics Gross domestic product in the expenditure approach (2008-2013) ', Pristina, Kosovo 
CBK, Monthly Statistical Buletin, Decembar 2014,Nr. 10, Prishtina, Kosovo

CBK, Report of makroekonomik Development,Nr. 2, February 2015, Prishtina, Kosovo

MTI,Report of industrial development in Kosovo,January 2014,Prishtina, Kosovo

Rea, Privat Sector and potential investments,Mars 2015, Prishtina

Statistical Office of Kosovo, Statistics of Forign Trade,January 2015, Prishtina, Kosovo

UNDP, Impact of tax regime in four producing sectors, 2014,Prishtina, Kosovo

Thematic Roundtable no. 4. (2012), Trade, industry, customs, tax, internal market, competition, consumer protection and health, Pristina,Kosovo

International Monetary Fond (,2013) Republic of Kosovo several selected issues, Strategy for cooperation on USAID for the development of the country of Kosovo 2014 -2018,

Government of Kosovo, (2011) Vision and Action Plan for the Economical Development,

USAID. (2012). Study on the effect of the irregular supply of electricity in Kosovo Businesses, World Bank, (2012). World Development Indicators

World Bank, (2013). Doing Business Report

USAID, (2012). Diagnosis of Growth in Kosovo: Analysis of Barriers 
